International Journal of Business Management and Economic Review

Vol. 4, No. 06; 2021

ISSN: 2581-4664

\title{
THE EFFECT OF GOVERNMENT ACCOUNTING STANDARD, QUALITY OF HUMAN RESOURCE, EFFECTIVENESS OF INTERNAL CONTROL SYSTEM AND REGIONAL FINANCIAL ACCOUNTING SYSTEM ON THE QUALITY OF REGIONAL GOVERNMENT FINANCIAL STATEMENT (Study on SKPK Aceh Singkil District. Aceh Province Indonesia)
}

\author{
Sri Mulyati, Ridwan Ibrahim and Muslim A. Djalil* \\ Magister of Accountancy Program, Faculty of Economics and Business, Universitas Syiah Kuala, Banda Aceh
}

http://doi.org/10.35409/IJBMER.2021.3338

\begin{abstract}
The purpose of this research is to examine the effect of government accounting standard, the quality of human resource, the effectiveness of the internal control system and the regional financial accounting system, either simultaneously or partially on the quality of local government financial report of Government Work Unit (SKPK) Aceh Singkil District. The population of this research is the SKPK of Aceh Singkil which includes 46 offices in the Regency. Each SKPK consists of 3 (three) people who will be respondents, namely the head of the SKPK or Budget User (PA), the head of the accounting department or the Financial Administration Officer (PPK) and the accounting staff or PPK Assistant, so the total number of respondents are 138 people. The research employs primary data through the acquisition of questionnaires from respondents. While the research data collection technique was carried out by using documentation tool, the analytical method used is Multiple Linear Regression Analysis. The results showed that government accounting standard, the quality of human resource, the effectiveness of the internal control system and the regional financial accounting system have a significant influence on the quality of local government financial reports of the regency.
\end{abstract}

Keyword: Government Accounting Standard, Human Resources Quality, Effectiveness Internal Control System, Financial Accounting System, Quality of Local Government Finance Report.

\section{INTRODUCTION}

The financial reports produced by the local government will be used by several interested parties as a basis for decision making. Therefore, the information c o n t a in e d in the Regional Government Financial Statements (LKPD) must be useful and in accordance with the needs of users of these financial statements. To achieve this goal, local governments are required to pay attention to the information presented in financial reports for planning, controlling, and decision-making purposes (Subagjo, 2013).

The phenomenon of local government financial reporting is an interesting thing to study further, as is the case with the financial reports of the Aceh Singkil district government. From various issues and information obtained from various sources, it is known that the Aceh Singkil District LKPD still has many findings or irregularities that 


\section{International Journal of Business Management and Economic Review}

Vol. 4, No. 06; 2021

ISSN: 2581-4664

were found by the BPK in the implementation of its audit.

Findings related to SPI include: The changes in the Aceh Singkil district government budget were not sufficient; and management of fixed assets is not yet fully adequate. Meanwhile, the compliance findings include: overpayment of three packages of activities at the Public Works and Public Housing (PUPR) Office; and the realization of subsidy spending to PDAM Tirta Singkil has not complied with the provisions (BPK Press Release, 2019).

Based on several problems that have been described previously, it can be judged that the Aceh Singkil District LKPD is not yet fully qualified, this has made public demands for accountability in local government financial management and the presentation of quality information is increasing. There are several factors that are thought to affect the quality of local government financial reports, namely;

Firstly, government accounting standards affects the quality of local government financial reports. In SAP, it regulates the accounting principles that must be applied in preparing and presenting central / regional government financial reports. Therefore, SAP is a requirement as well as a guideline that has legal force in an effort to improve the quality of government financial reporting information both at the central and regional levels. This is in accordance with the research results of Rahayu (2014), Nurlis (2018), Mahaputra and Putra (2014) and Juwita (2013) which prove that government accounting standards have a significant effect on the quality of financial statements.

Secondly, the quality of human resources affects the quality of local government financial reports . Roviyantie (2011) states that financial reports are a product produced by the field or discipline of accounting, therefore, to produce a quality financial report requires human resources who understand and are competent in government accounting, regional finance and even organizational governance. This is in accordance with the results of research by Setyowati, Isthika and Pratiwi (2016), Andini and Yusrawati (2015), Mahaputra and Putra (2014), Nuryanto and Afiah (2013) which show that the quality of human resources has an influence on the quality of government financial reports area.

Thirdly, the effectiveness of SPI affects the quality of local government financial reports. In order to provide adequate assurance regarding the achievement of local government objectives as reflected in the reliability of financial reports, efficiency and effectiveness of program and activity implementation and compliance with laws and regulations, a regional financial supervision process is required. This is in accordance with the results of research by Afiah and Azwari (2015), Mahaputra and Putra (2014), Nuryanto and Afiah (2013) which provide results that SPI affects the quality of local government financial reports. Fourthly, the local financial accounting system affects the quality of local government financial reports. SIKD provides benefits or convenience in processing regional financial management data and other related data into information presented to the public and as a basis for decision making in the framework of planning, implementing, and reporting the accountability of local governments. Thus the use of SAKD in the process of preparing financial reports will be able to improve the quality of information in financial reports. This is in accordance with the results of research by Andini and Yusrawati (2015), Dewi and Mimba (2014), Mahaputra and Putra (2014), Nuryanto and Afiah (2013) and Juwita (2013) which have proven that the regional financial accounting information system has an effect on quality. local government financial reports. 


\section{International Journal of Business Management and Economic Review}

Vol. 4, No. 06; 2021

ISSN: 2581-4664

Based on the background of research conducted previously, and by looking at the current phenomena that are happening within the scope of the Aceh Singkil Regency Government, the purpose of this study is to examine the effect of government accounting standards, the quality of human resources, the effectiveness of the internal control system and the financial accounting system. regions jointly on the quality of local government financial reports on SKPK Aceh Singkil.

\section{LITERATURE REVIEW}

\section{Quality of Local Government Financial Reports}

According to the Regulation of the Minister of Home Affairs Number (Permendagri) Number 19 According to Nordiawan and Hertianti (2011: 44) the quality of financial reports is normative measures that need to be manifested in accounting information so that it can fulfill its objectives, in order to meet the desired quality government financial reports must meet four characteristics, namely relevant, reliable, comparable and understandable. According to Harahap (2009: 146), the quality of financial reports is a criterion for the requirements of financial accounting reports that are considered to fulfill the wishes of users or readers of financial statements. The criteria for the quality of financial reports lead to the information generated that will be useful in making decisions (Suwardjono, 2005: 164-177). From some of the previous definitions, it can be said that the quality of financial reports is the measures used so that the information generated can be useful for its users.

\section{Government Accounting Standard}

Governmental Accounting Standards are the legal basis for both Central and Regional Government officials in managing the receipt and use of funds in a transparent, efficient and accountable manner so that the goal of realizing transparency and accountability can be achieved. The financial reports generated from the accrual-based SAP application are intended to provide better benefits to stakeholders, both users and auditors of government financial reports, compared to the costs incurred. This is in line with one of the accounting principles, namely the costs incurred are proportional to the benefits obtained. The purpose of implementing this SAP is to regulate the presentation of general purpose financial statements in order to improve the comparability of financial reports both against budgets, between periods and between entities. General purpose financial reports are financial reports that are intended to meet the common needs of most report users, including the legislature as defined in the provisions of laws and regulations.

\section{Quality of Human Resources}

HR is an ability that every human being has. Quality human resources can be seen in the results of their work. According to Almasdi (2006: 17) human resources are the power of thought and human work that are still stored within them which need to be nurtured and explored and developed to be used as well as possible for the welfare of people's lives. Hasibuan (2003: 244) states that human resources are "the integrated ability of the thinking power and physical power of an individual". Another opinion from Rivai and Basri (2005: 421), states that human resources are "elements of support and support for the implementation of activities consisting of manpower, funds and infrastructure". Another party, Sedarmayanti (2009: 30) states that human resources 


\section{International Journal of Business Management and Economic Review}

Vol. 4, No. 06; 2021

ISSN: 2581-4664

are "core competencies in an organization". Some of the ways human resources become a core competency is by attracting and maintaining them with professional and technical skills in training and development. The quality of human resources is the level of a person's ability to carry out the tasks and responsibilities given to him with adequate education, training and experience. This is because humans are one of the most important organizational elements, therefore it must be ensured that human resource management is carried out as well as possible in order to be able to contribute optimally in the effort to achieve organizational goals (Widodo, 2001).

\section{Effectiveness of Internal Control System}

Effectiveness is the relationship between output and objectives, the greater the contribution (contribution) of output to the achievement of goals, the more effective the organization, program or activity is. Effectiveness focuses on outcomes (results), programs, or activities that are considered effective if the resulting output can meet the expected objectives or it is said to be spending wisely. In this connection, the effectiveness describes the entire cycle of input, process and output which refers to the useful results of an organization, program or activity which states the extent to which the objectives (quality, quantity, and time) have been achieved, as well as a measure of the success or failure of an organization to achieve its objectives. and achieve its targets (Mahmudi, 2005:92). According to Government Regulation Number 60 of 2008 concerning Government Internal Control System Article 1 states that the internal control system is an integral process of actions and activities carried out continuously by the leadership and all employees to provide adequate confidence in the achievement of organizational goals through effective activities. and efficiency, reliability of financial reporting, safeguarding state assets, and compliance with laws and regulations. Government Internal Control System, hereinafter abbreviated as SPIP, is an Internal Control System that is carried out comprehensively within the central government and regional governments.

\section{Regional Financial Accounting System}

According to Rommey and Steinbart (2009: 2) the notion of a system is a series of two or more interconnected components that interact to achieve a goal. Mulyadi (2001: 3) provides an understanding of the accounting system as forms, records, and reports that are coordinated in such a way as to provide financial information needed by management to facilitate organizational management. Furthermore, Pemendagri No.64 of 2014 article 1 states that the Regional Financial Accounting System (SAKD) is a systematic series of procedures, administrators, equipment and other elements to realize the accounting function from transaction analysis to financial reporting within local government organizations. According to Darise (2008: 41) the definition of a regional financial accounting system is as a series of processes or procedures, starting from recording, classifying and summarizing financial transactions and/or events as well as financial reporting in the framework of accountability for the implementation of the APBD.

\section{RESEARCH METHOD}

The population of this research is the SKPK Aceh Singkil which includes 46 offices, offices and agencies in Aceh Singkil Regency. Each SKPK consists of 3 (three) people who will be respondents, namely the head of the SKPK or Budget User (PA), the head of the accounting 


\section{International Journal of Business Management and Economic Review}

Vol. 4, No. 06; 2021

ISSN: 2581-4664

department or the Financial Administration Officer (PPK) and the accounting staff or PPK Assistant, so the total number of respondents is 138 people. The source of data in this study uses primary data that is the acquisition of questionnaires from respondents. While the research data collection technique is done by the documentation technique. The analytical method used is Multiple Linear Regression Analysis.

Operationalization of variables in this study can be described as follows;

a. Government Accounting Standards (X1)

SAP is the application of accounting principles in preparing and presenting local government financial reports. The indicators used are based on PP. 71/2010; the conceptual framework, components and elements of financial statements, understanding the recognition of elements in financial statements, and measurement of elements of financial statements. The scheme used is a 5-point Likert model interval scale.

b. Quality of Human Resources (X2)

According to Widodo (2001) the quality of human resources is the level of a person's ability to carry out the tasks and responsibilities given to him with sufficient education, training and experience. The indicators used are based on Widodo (2011); education and expertise, job descriptions and responsibilities, supporting resources, job skills training. The scheme used is a 5-point Likert model interval scale.

c. Effectiveness of Internal Control System (SPI) (X3)

The effectiveness of SPI is a system consisting of policies, procedures, methods and regulations set by an organization so that the plans and objectives of the organization can be achieved properly. The indicators used are based on PP. 60 of

2008; control environment, risk assessment, control activities, information and communication, internal control monitoring. The scheme used is a 5-point Likert model interval scale.

d. Regional Financial Accounting System (X4)

According to Darise (2008:41) the definition of a regional financial accounting system is as a series of processes or procedures, starting from recording, classifying and summarizing financial transactions and/or events as well as financial reporting in the framework of accountability for the implementation of the APBD. The indicators used are based on Pemendagri No.59 of 2007; Recording, Summarizing and Reporting. The scheme used is a 5-point Likert model interval scale.

e. Quality of Local Government Financial Report (Y)

According to Nordiawan and Hertianti (2011:44) the quality of financial reports is normative measures that need to be embodied in accounting information so that it can fulfill its objectives, in order to meet the desired quality. The indicators used are based on PP. 71 of 2010 which is relevant; reliable; comparable; and can be understood. The scheme used is a 5-point Likert model interval scale.

\section{RESULTS AND DISCUSSIONS \\ Results}

Descriptive Analysis

Descriptive analysis for each variable in this study was obtained by 
Vol. 4, No. 06; 2021

ISSN: 2581-4664

questionnaires filled out by respondents to the variable; quality of local government financial reports (LKPD) (Y), government accounting standards (SAP) (X1), the quality of human resources (HR) (X2), the effectiveness of the internal control system (SPI) (X3), and the regional financial accounting system (SAKD) (X4). The following are descriptive statistical values for each of the research variables in Table 1.

\section{Tabel 1Descriptive statistics}

\begin{tabular}{|c|c|c|c|c|c|}
\hline $\begin{array}{l}\text { Statistical } \\
\text { Value }\end{array}$ & $\begin{array}{l}\text { Ounlitv } \\
\text { Government } \\
\text { Financial } \\
\text { Reports }\end{array}$ & $\begin{array}{l}\text { Tnvernment } \\
\text { Accounting } \\
\text { Standards } \\
\text { (X1) }\end{array}$ & $\begin{array}{l}\text { Nuality of } \\
\text { Human } \\
\text { Resource } \\
\mathrm{S}\end{array}$ & 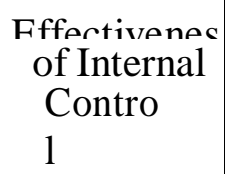 & $\begin{array}{l}\text { Reoinnal } \\
\text { Financial } \\
\text { Accounting } \\
\text { System } \\
\end{array}$ \\
\hline Aver & 4,08 & 4,24 & 4,21 & 4,04 & 4,13 \\
\hline Standard & 0,20 & 0,26 & 0,23 & 0,33 & 0,22 \\
\hline $\begin{array}{l}\text { Minimum } \\
\text { Maximum }\end{array}$ & $\begin{array}{l}3.67 \\
4,70 \\
\end{array}$ & $\begin{array}{l}3.67 \\
4,70 \\
\end{array}$ & $\begin{array}{l}3.71 \\
4,70\end{array}$ & $\begin{array}{l}2.93 \\
4,70 \\
\end{array}$ & $\begin{array}{l}3.50 \\
4,70\end{array}$ \\
\hline
\end{tabular}

Based on the results of descriptive statistics, it can be seen that the four research variables, the quality of local government financial reports $(\mathrm{Y})$, government accounting standards $\left(\mathrm{X}_{1}\right)$, the quality of human resources $\left(\mathrm{X}_{2}\right)$, the effectiveness of the internal control system $\left(\mathrm{X}_{3}\right)$, and the accounting system. Regional finance (X4) show an average value greater than the standard deviation value. This indicates that the four research variables have a more stable rate of data distribution. It can also be seen from the difference in the minimum and maximum values of the four variables which have a range that is not too far.

\section{Research Instrument Testing Results}

a. Based on the results of testing the validity shows that the correlation coefficient obtained from each variable item government accounting standards (X1), the quality of human resources $\left(\mathrm{X}_{2}\right)$, the effectiveness of the internal control system (X3), and the accounting system. Regional finance (X4) are all above critical value of product moment correlation (correlation coefficient> 0,291 ) so that the questionnaire used can be declared valid.

b. Based on the reliability test in mind that each instrument in this study reliable (reliably) because the value Cronb ach's Alpha greater than 0,6 . So it can be concluded that the questionnaire used as a measurement tool in this study is feasible to use (reliable).

\section{Classical Assumption Testing Results}

Based on the histogram graph, it is known that the observation data is normally distributed where the curve is normal. While the P-Plot graph is known that the points move in the direction of the linear line, so it can be concluded that the research regression model is linear. 
International Journal of Business Management and Economic Review

Vol. 4, No. 06; 2021

ISSN: 2581-4664

Based on the figure tolerance of variable of government accounting standards ( $\left.\mathrm{X}_{1}\right)$, the quality of human resources ( $\left.\mathrm{X}_{2}\right)$, the effectiveness of the internal control system (X3), and the accounting system. Regional finance $(\mathrm{X} 4)>0,10$, which means that no multicolinearity between the independent variables. Meanwhile, the VIF value calculation results also showed that none of the independent variables that have a VIF value of more than 10 . Thus, it can be concluded that in this study the regression model did not happen multikoline a rity between the independent variables. From the graph scatterplot is known that there is no particular pattern in the chart, therefore it can be concluded that the regression model in this study is homoskedastisitas or not happen heteroskedastisitas.

Regression Testing Results

The results of testing the research regression can be seen in Table 2 .

Table 2 Research Regression Testing Results

\begin{tabular}{|c|l|c|c|c|}
\hline No. & Variable Name & $\begin{array}{l}\text { Regressio } \\
\mathrm{n} \\
\text { Conffinin }\end{array}$ & $\begin{array}{l}\text { Informatio } \\
\mathrm{n}\end{array}$ & Conclusion \\
\hline 1 & Government Accounting Standards & 0.280 & $\beta \neq 0$ & Take effect \\
\hline 2 & Ouality of Human Resources & 0,117 & $\beta \neq 0$ & Take effect \\
\hline 3 & $\begin{array}{l}\text { Effectiveness of Internal Control } \\
\text { Svstems }\end{array}$ & 0,163 & $\beta \neq 0$ & Take effect \\
\hline 4 & Regional Financial Accounting & 0,243 & $\beta \neq 0$ & Take effect \\
\hline
\end{tabular}

Based on the results of the regression tests, the multiple linear regression equation is obtained as follows:

$$
Y=2,749+0,280 X_{1}+0,117 X_{2}+0,163 X_{3}+0,243 X_{4}+\varepsilon
$$

\section{Discussions}

The Effect of Government Accounting Standards on the Quality of Local Government Financial Statement

The results showed that SAP affects the quality of LKPD. The regression coefficient ( $\beta 1)$ obtained is 0,280 , indicating that each increase in SAP 1 interval scale unit will be followed by an increase in the quality of LKPD of 0,280 units of interval scale. Obtained a positive effect of SAP on the quality of LKPD. This means that if SAP is implemented properly and implemented in accordance with the rules set out in each SKPK in Aceh Singkil Regency, the resulting LKPD will be of higher quality.

Based on the results of respondents' answers from distributing questionnaires, it is known that the average respondent agrees that the financial statements of the institution have referred to the stipulated SAP. All respondents also answered that the agencies they worked for had presented (5) five main financial reports (Budget Realization Report, Balance Sheet, Operational Report, Change in Equity Report, and Notes to Financial Statements). This means that SAP has become a reference used by regional officials in preparing financial reports in Aceh Singkil Regency. With the issuance of Government Regulation Number 71 of 2010 concerning Government Accounting Standards, there is clarity and firmness of the standards used by Aceh Singkil Regency. 
International Journal of Business Management and Economic Review

Vol. 4, No. 06; 2021

ISSN: 2581-4664

The results of this study are in accordance with the results of research conducted by Juwita (2013) which provides empirical evidence that a good SAP implementation will improve the quality of financial reports in district/city governments in West Java Province as Government Regulation Number 24 of 2005 concerning Government Accounting Standards (SAP). The results of this study are also consistent with the results of research by Nurlis (2018), Mahaputra and Putra (2014) and the results of Rahayu's (2014) research which prove that SAP has a significant effect on the quality of regional financial reports.

\section{The Influence of the Quality of Human Resources on the Quality of Local Government Financial Report}

The results showed that the quality of human resources had an effect on the quality of LKPD. The regression coefficient $(\beta 2)$ obtained is 0,117 indicating that every increase in the quality of human resources by 1 unit of interval scale will be followed by an increase in the quality of LKPD by 0,117 units of interval scale. Obtained a positive influence on the quality of human resources on the quality of LKPD. This means that if the regional apparatus in the agencies in Aceh Singkil Regency has good quality human resources, it can improve the quality of the Aceh Singkil District LKPD itself.

Based on the acquisition of the questionnaire, it was concluded that the average quality (HR) of the SKPK Aceh Singkil Regency was in the good category. This can also be seen from the level of education of the respondents, most of whom are undergraduate (S1) and Masters (S2). In addition, the variety of majors that the respondents have is also useful in completing and doing their respective assignments according to their skills. Research respondents who are also human resources at each SKPK also have quite a long work experience, this can be seen from the number of respondents who on average are dominated by officers aged 45 to over 55 years with a length of work over 10 years. This data means that the older the apparatus is, the longer it has worked, meaning that the apparatus has had experience and mastery of their respective fields of work over the length of time they have worked.

This is in accordance with the results of research by Setyowati, Isthika and Pratiwi (2016), Andini and Yusrawati (2015), Mahaputra and Putra (2014), Nuryanto and Afiah (2013) which show that the quality of human resources has an influence on the quality of government financial reports. local government.

\section{Effect of Internal Control System Effectiveness on Quality of Local Government Financial Report}

The results showed that the effectiveness of the SPI had an effect on the quality of the LKPD. The regression coefficient $(\beta 3)$ obtained is 0,163 , indicating that each increase in the effectiveness of the SPI by 1 interval scale unit will be followed by an increase in the quality of LKPD of 0,163 interval scale units. Obtained a positive effect of the effectiveness of SPI on the quality of LKPD. This means that if the regional government has implemented the SPI effectively, the quality of the Aceh Singkil District LKPD will increase.

Based on the results of obtaining research questionnaires, it shows that each SKPK in Aceh Singkil Regency is capable of carrying out control activities as outlined by government regulations. This is because the internal control in each SKPK can be implemented 
effectively, which means that effective SPI affects the quality of local government financial reporting. These results indicate that internal control actually determines the quality of regional financial reports (Setiawati and

Sari, 2014).

The results of this study are in line with the results of research conducted by Yuliani, Nadirsyah and Bakar (2010) which proved that the role of internal audit has a positive and significant effect on the quality of LKPD. The results of this study are also consistent with the results of research by Afiah and Azwari (2015), Mahaputra and Putra (2014), Nuryanto and Afiah (2013) that provide results that SPI affects the quality of local government financial reports.

\section{The Effect of Regional Financial Accounting Systems on the Quality of Local Government Financial Statements}

The results showed that SAKD had an effect on the quality of LKPD. The regression coefficient ( $\beta 4$ ) obtained is 0,243 indicating that each increase in SAKD of 1 unit of interval scale will be followed by an increase in the quality of LKPD of 0,243 units of interval scale. Obtained a positive effect of SAKD on the quality of LKPD. This means that if SAKD has been carried out properly by officials at the SKPK in Aceh Singkil Regency, the quality of the LKPD can increase.

The results of this study are in accordance with the mandate implied in the explanation of Government Regulation Number 56 of 2005 concerning Regional Financial Information Systems, which states that the Government and Regional Governments are obliged to develop and take advantage of advances in information technology to improve the ability to manage regional finances and distribute Regional Financial Information to public services. With the rapid advancement of information technology and the potential for widespread use, it can open opportunities for various parties to access, manage and utilize regional financial information quickly and accurately. This indicates that the better the use of information technology, the better the quality of local government financial reports.

The results of this study are also consistent with the results of research conducted by Andini and Yusrawati (2015), Dewi and Mimba (2014), Mahaputra and Putra (2014), and Nuryanto and Afiah (2013) which have proven that regional financial accounting information systems affect quality of local government financial reports.

\section{CONCLUSIONS AND SUGGESTIONS Conclusions}

The government accounting standard, the quality of human resource, the effectiveness of the internal control system and the regional financial accounting system have a significant effect on on the quality of local government financial reports on SKPK Aceh Singkil, either simultaneously or partially

\section{Recommendations}

1. It recommended for top officials of Aceh Singkel Regency to create policies related to regional financial reporting, because it would lead to the success of the apparatus in presenting the agency's financial report and in turn it would further improve the quality of the financial report of the Aceh Singkil regency 
2. In addition, there is a need for consistency of the Aceh Singkil Regency Government in training activities on SAP within the SKPK. This activities are expected to improve the quality of regional apparatus, commitment to running SPI and increasing its capacity.

3. The regional government of Aceh Singkil Regency also needs to provide guidance to ASN so that it is sustainable given the large number of respondents who are about to enter retirement.

\section{REFERENCES}

Afiah, N. N. \& P. C. Azwari. (2015). The Effect of the Implementation of Government Internal Control System on the Quality of Financial Reporting of the Local Governemnt and its Impact on the Principles of Good Governance. Procedia Social and Behavioral Sciences, 811-818.

Almasdi, Y. (2006). Aspek Sikap Mental dalam Manajemen Sumber Daya Manusia Indonesia. Jakarta: Ghalia Indonesia.

Andini, D. dan Yusrawati. (2015). Pengaruh Kompetensi Sumber Daya Manusia Dan Penerapan Sistem Akuntansi Keuangan Daerah Terhadap Kualitas Laporan Keuangan Daerah. Jurnal Ekonomi, Manajemen dan Akutansi I. 24 (1), 65-82.

Darise, N. (2008) Pengelolaan Keuangan Daerah. Jakarta: PT. Indeks.

Dewi, P. A. R, \& N. P. S. H. Mimba (2014) Pengaruh Efektivitas Penerapan Sistem Informasi Pengelolaan Keuangan Daerah (SIPKD) pada Kualitas Laporan Keuangan. E-Jurnal Akuntansi Universitas Udayana, 8(3), 442-457.

Harahap, S. S. (2009). Analisis Kritis Atas Laporan Keuangan. Jakarta: Raja Grafindo Persada.

Hasibuan, M. (2003). Manajemen Sumber Daya Manusia. Edisi Revisi. Jakarta: Bumi Aksara.

Juwita, R. (2013). Pengaruh Implementasi Standar Akuntansi Pemerintahan dan Sistem Informasi Akuntansi Terhadap Kualitas Laporan Keuangan. Trikonomika, 12 (2), 201214.

Mahaputra, I P. U. R., dan I W. Putra. (2014). Analisis Faktor-Faktor yang Memengaruhi Kualitas Informasi Pelaporan Keuangan Pemerintah Daerah.E- Jurnal Akuntansi Universitas Udayana. 8 (2), 230-244.

Mahmudi. (2010). Analisis Laporan Keuangan Pemerintah Daerah: Panduan Bagi Eksekutif, DPRD dan Masyarakat dalam Pengambilan Keputusan Ekonomi, Sosial dan Politik. Edisi ke-2. Yogyakarta: UPP STIM YKPN.

Mulyadi. (2001). Analisis Pengaruh Faktor-faktor Good Governance terhadap Kualitas Pelayanan Bagi Wajib Pajak. Jakarta: BINUS University.

Nordiawan, D. dan A. Hertianti. (2011). Akuntansi Sektor Publik. Jakarta: Salemba Empat.

Nurlis. (2018). The Effect of The Government Accounting Standards Implementation and Apparatus Competency on the Quality of the Local Government Financial Reporting. Research Journal of Finance and Accounting, 9 (8), 63-69.

Nuryanto, M. \& N. N. Afiah. (2013). The Impact of Apparatus Competence, Information Technology Utilization and Internal Control on Financial Statement Quality. World Review of Business Research, 3 (4), 157-171.

Rahayu, S. K., dan E. Suhayati. (2010). Auditing Konsep dasar dan pedoman 
International Journal of Business Management and Economic Review

Vol. 4, No. 06; 2021

ISSN: 2581-4664

Pemeriksaan Akuntan Publik. Yogyakarta: Graha Ilmu.

Republik Indonesia. Peraturan Pemerintah Nomor 58 Tahun 2005 Tentang Pengelolaan Keuangan Daerah.

------. Peraturan Menteri Dalam Negeri Nomor 59 Tahun 2007, dan terakhir di ubah dengan Permendagri Nomor 21 Tahun 2011 Tentang Pedoman Pengelolaan Keuangan Daerah.

-------. Peraturan Menteri Dalam Negeri Nomor 64 Tahun 2013 Tentang Penerapan Standar Akuntansi Pemerintahan Berbasis Akrual pada Pemerintah Daerah.

-------. Peraturan Pemerintah Nomor 60 Tahun 2008 tentang Sistem Pengendalian Intern Pemerintah (SPIP)

-------. Peraturan Pemerintah Nomor 71 Tahun 2010 Tentang Standar Akuntansi Pemerintah.

Rivai, V. \& A. F. M. Basri. (2005). Performance Appraisal Sistem yang Tepat untuk Menilai Kinerja Karyawan dan Meningkatkan Daya Saing Perusahaan. Jakarta: PT. Raja Grafindo Persada.

Romney, M. B. \& P. J. Steinbart. (2009). Accounting Information System. USA: Cengage Learning.

Roviyantie, D. (2011). Pengaruh Kompetensi Sumber Daya Manusia dan Penerapan Sistem Akuntansi Keuangan Daerah terhadap Kualitas Laporan Keuangan Daerah. Jurnal Ekonomi Akuntansi. Universitas Sliwangi Tasikmalaya.

Sedarmayanti. (2009). Good Governance (Kepemerintahan yang Baik). Bandung: Mandar Maju. Setiawati, E. \& S. P. Sari. (2014). Kualitas Pelaporan Keuangan Pemerintah Daerah Ditinjau dari Sumber Daya Manusia, Pengendalian Intern, Pemanfaatan Teknologi Informasi dan Pemahaman Akuntansi. Syariah Paper, 427-444. Artikel online melalui https://publikasiilmiah. ums.ac.id/handle/11617/4601?show=full. Diakses pada 15/09/2019.

Setyowati, L., W. Isthika., \& R. D. Pratiwi. (2016). Faktor-Faktor Yang Mempengaruhi Kualitas Laporan Keuangan Pemerintah Daerah Kota Semarang. Kinerja, 20 (2), 179-191.

Siaran Pers, BPK. (2019). Penyerahan laporan Hasil Pemeriksaan Atas laporan

Keuangan Pemerintah Kabupaten Aceh Singkil Tahun Anggaran 2018.

Subagjo, R. A. (2013). Pengaruh Profesionalisme, Pengetahuan tentang Pengelolaan Keuangan Daerah, dan Intensitas Pembinaan Aparat Inspektorat terhadap Kualitas Laporan Keuangan Pemerintah Daerah. Artikel online melalui Repository.Unej.Ac.Id. Diakses pada 28/02/2015.

Suwardjono. (2005). Teori Akuntansi: Perekayasaan Pelaporan Keuangan. Edisi Ketiga. Yogyakarta: BPFE.

Widodo, J. (2001). Good Governance: Telaah dan Dimensi Akuntabilitas dan Kontrol Birokrasi pada Era Desentralisasi dan Otonomi Daerah. Surabaya Insan Cendekia: Surabaya.

Yuliani, S., Nadirsyah, \& U. Bakar (2013) Pengaruh Pemahaman Akuntansi, Pemanfaatan Sistem Informasi Keuangan Daerah Dan Peran Internal Audit Terhadap Kualitas Laporan Keuangan Pemerintah Daerah. Jurnal Telaah Dan Riset Akuntansi., 3 (2), 206-220. 